\title{
Swettenham's Work Malay Sketches and the Myth of Lazy Malays Issues: Re-Evaluation in Welcoming Industrial Revolution 4.0
}

\section{Noordin Mohd Noor}

School of Languages, Literacy \& Translations Universiti Sains Malaysia

\section{Abstract}

The industrial revolution that took place in Europe in the early stages caused colonialism in Southeast Asia countries, particularly Britain in Malaya (Tanah Melayu). The English colonization opened up space in literature as some of the colonial officials wrote their autobiographical works or travelogues bearing their experiences witnessed the societies and cultures of the colonies. At the same time there were some English officials from the British East India sentenced to work in Malaya who took the opportunity to record their travel experiences living here with Malay peoples. Swettenham is one of them. But what is not quite good to know is that they recorded

Corresponding Author: Noordin Mohd Noor Noordin@usm.my

Received: 1 July 2019

Accepted: 18 July 2019

Published: 31 July 2019

Publishing services provided by Knowledge

(c) Noordin Mohd Noor. This article is distributed under the terms of the Creative Commons Attribution License, which permits unrestricted use and redistribution provided that the original author and source are credited.

Selection and Peer-review under the responsibility of the AICLL 2019 Conference Committee.

\section{G OPEN ACCESS} negative things about Malays. The statements are not exactly accurate. This is because it is merely a personal view from the colonial perspectives. This paper intends to address the issue of Laziness Malay myth by citing Swettenham's statements in his travelogue entitled Malay Sketches. Frank Swettenham, (born March 28, 1850,Belper, Derbyshire, Eng.--died June 11, 1946, London), British colonial official in Malaya who was highly influential in shaping British policy and the structure of British administration in the Malay Peninsula. He learned the Malay language and played a major role as British-Malay intermediary in the events surrounding British intervention in the peninsular Malay states in the 1870s. He successfully promoted the development of coffee and tobacco estates in the Malay state and helped boost tin earnings by constructing a railway from Kuala Lumpur. His services help to energize the industrial revolution in England. This conference is a literary privilege that gives scholars the opportunity to give a feed back to this Englishman's allegations to the Malays.

Keywords: Travelogue, Myth, Laziness, Occidental.

\section{Introduction}

We have already felt the beginning of this new world. Millions of people are now connected to mobile devices that now also allow instant access and are not limited to the world of knowledge over the internet. Smart systems that control homes, factories, farms and even cities around the world help resolve all issues from supply chain management to climate change. 
The previous industrial revolution in Europe occurred in the eighteen centuries has caused the arrival of English power in Southeast Asia and is ending with colonization. English colonialists use Malay land as a source of rubber and tin to expand their industrial sectors. At the same time, the arrival of English in Malaya was also indirectly interfered the Malay life and culture. Something about the English is that they love to write their travel or adventure stories. Just to mention an example, while colonizing India a novel titled Passage to India is produced as an example.

There were some English officials who wrote their views or in other word known as travelogue about the Malays. One of them is Frank Swettenham. Frank Athelstan Swettenham was a British colonial administrator who became the first Resident general of the Federated Malay States, which brought the Malay states of Selangor, Perak, Negeri Sembilan and Pahang together under the administration of a Resident-General based in Kuala Lumpur. What is the connection between Swettenham and literature or literary studies? The discussions will be elaborated later on in this paper:

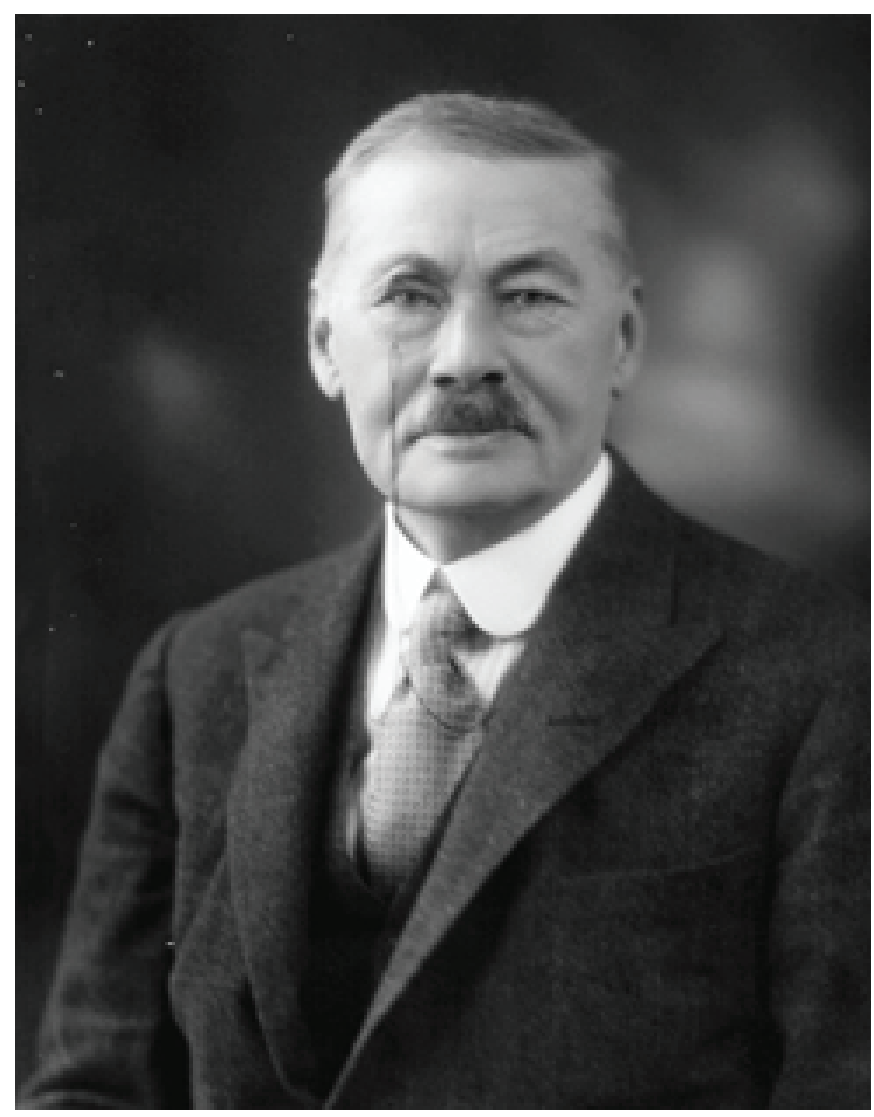

Figure 1: Mr Sir Frank (Athelstane) Swettenham. 


\section{Literature Review \& Occidentalism in Literature Studies}

Let us move on the discussion of the word origin and the history of occidental. Occidental is originally from Old French occidental (14c.) and directly from Latin. Occidentalist means "western". As a capitalized noun meaning "a Western person" (opposed to Oriental) from 1857. This is according to Etymology Dictionary, (c) 2010 Douglas Harper. The definition of Occidentalism is not easy to get or almost no westerners define this term. It is believe this is so, due this term covers the purpose of studying and exploring how they see the colonized people.

Occidentalism in literature studies is a discipline that discusses the Western world. In this context the West becomes an object, while the East is the subject. Unlike the study of East (orientalism) which is rarely done, the study of the West (Occidentalism) is still unpopular to the general public or even academic circles. The West in the context of occidism does not lead to the West in geographically, but culturally or primarily covering areas of thought, philosophy, sociology, anthropology, history, religion, and geography.

Frank Swettenham wrote a travelogue known as Malay Sketches. From this discourse he has sketched the Malay people's life and culture from his perspective or point of view as an Englishman particularly. Let's get to know a little about the discourse:

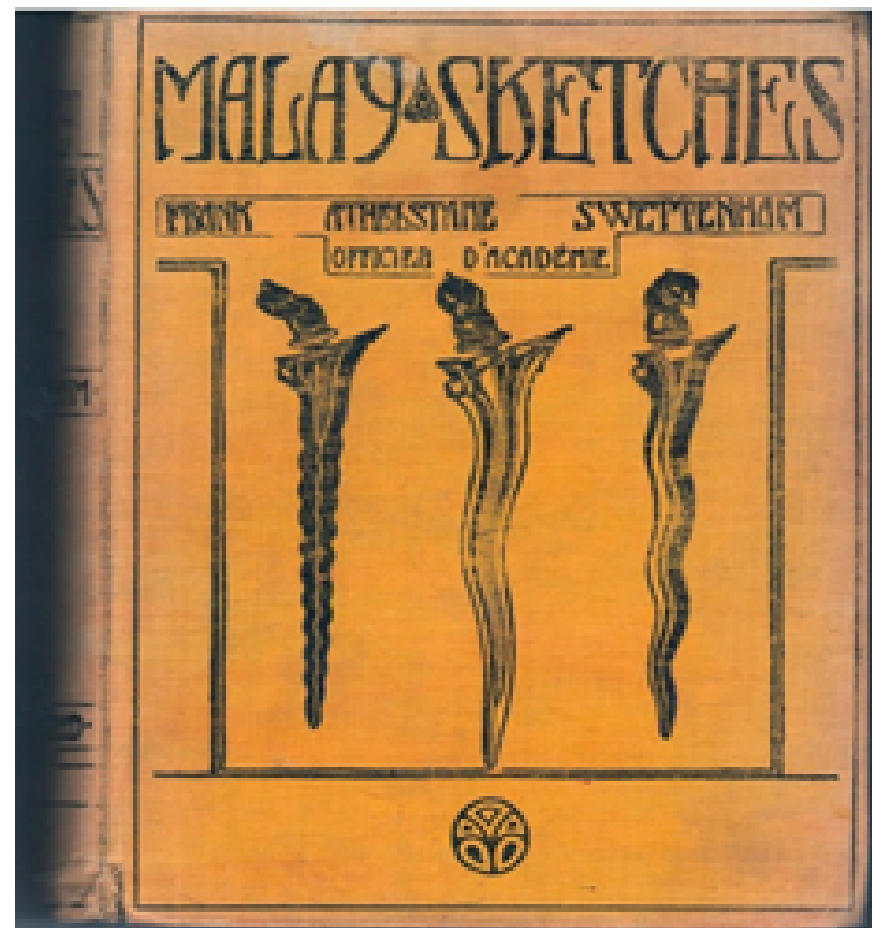

This book or in literature also known as a travelogue contains a series of sketches of the lush scenery in tropical Malaya, observations of the characteristics of the Malays, 
descriptions of their lives, customs, beliefs and superstitions, portraits of some personalities and personal accounts of experiences, events and incidences encountered by Frank Swettenham during his stay in Malaya.

\section{Research Method}

This paper applied the library research method in theory matters. While the approach used to study the material is a text analysis. Swettenham's notes in his travelogue regarding the Malays culture and life styles are quoted and discussed.

\section{Discussions}

Swettenham in his book Malay Sketches stated that the Malays were primitive, lethargic, and confrontational and resist to modernization. Furthermore according to him, the community loves to spend time by carrying out useless things such as gambling, cockfighting and sleeping. He also projects that Malay is a Fatalistic believer, who unattached to the teachings of Islam, in fact believing superstitious of shaman and others. Swettenham also described Malay with negative attitudes such as lavish, rampage (amok), surrender to destiny and despair. Swettenham by a glance recorded his observations about Malay peoples life style vis.a.vis so did my reply to his observations.

To make it easier for the reader of this paper, Swettenham describes the Malays as the following list below:

1. The Malays like to borrow money, but reluctant to pay it back

Reply: It is true, no doubt that it is easier when we want to borrow money from someone or from finance agency, but it is hard for us to commit when it's the time to pay back. Well, perhaps Mr. Swettenham has a genuine heart and never experience short of cash until he needs to borrow from others.

In conclusion, this is not quite fair to accuse only the Malays have this kind of bad habits. This case happens everywhere and every time.

2. Malays like to know the affairs of neighbors and gossiping.

Reply: This statement is rather funny and entertaining to the readers of Malay Sketches. In English it is known as busy body. If in English known the term busy body, meaning this kind of attitude occurs in English's life as well. Therefore this is not something strange to everybody. 
3. Malay peoples like to believe in shaman or witch doctor when they get sick.

Reply: This fact is true, traditional medicine is the only way of care that exists when Swettenham was around at that time. Yes, he would not understand this cultural element which is to see as it is a negative element. Shaman, Healer or witch doctor also existed in the western culture before the era of renaissance but the practice slowly disappeared. Further after they experienced an industrial revolution healer or witch doctor is totally not in the picture anymore.

4. Malay people like gambling.

Reply: Gambling has taken place, in some form or other, for hundreds if not thousands of years, and is inextricably linked to the history of humanity. From ancient China where indications of rudimentary games of chance were discovered on tiles, to Egypt where the oldest known dice were excavated, to scenes on Greek and Roman potteries which indicate that betting on animal fights was common and animals would be bred for that sole purpose, humans love to gamble and do so at every opportunity. For Malaya case, Swettenham forgot that who brought in the horse racing to Malaya? Until now horse racing exist in Malaysia and Singapore.

5. Not easy to accept any changes.

Old habits die hard, accepting a sudden change is a cultural shock to all of us and happens to all nations or races. Furthermore, in the case of English elements to be applied to the Malays, undoubtedly in its early stages it will be abandoned. Even so, little by little the English element began to influence upper Malays, through English education and everyday life styles mingling with the English community in Malaya.

6. Malay peoples are sometimes lazy, but even routine things are neglected.

Reply: The Malays at that time were self-employed, only a few who served the English. The self-employed Malays like a farmer, fisherman and carpenter, home and boat builder are lazy to Swettenham's point of view. Actually the truth is, this group of peoples does not want to work with the English. Those who do not want to work with English are what the Colonial says lazy people. (Hussein Al-Attas 1977). They refused to be a "slave" to a white man (hamba orang putih).

7. Malays do not appreciate the time.

Reply: Indeed, those Malay peoples at that time did not work as the same as working in the office, perhaps this life style being neglected to notice by Swettenham, farmers work depending on the season, for carpenters they would work 
depending on customer demand. Business activities and urban life majority are immigrants who live in town. Malay's time refer to praying time, five times a day. It is always will be before or after praying time e.g. "I'll see you after Zuhr", or " we will meet before Asr".

8. House of Malays in that period was seen to be messy, even dirty.

Reply: Malay houses built of wood and not constructed using bricks. Swettenham is less appreciative of the art of Malay engraving and building without using nails. The original color of wood, bamboo and rumbia roof or nipah cooler if the weather is hot. The advantages of this wooden building advantage failed to be acknowledged by him.

9. The Malay people at that time were revengeful, and if the revenge cannot be repaid to the right people, anyone who happens to be near will be victims, regardless of men or women, old or young. Not all only those have guts will eye for an eyes.

Reply: Generally all humans are the same in this particular case. For the Malays the Islamic religion forbids the bad acts of revenges as well. Furthermore there is a suitable sentence to counter this matter based on Islamic teaching. Although there were times when emotions override the rationale. If we read Alexander Dumas story of the Count of Monte Cristo, everything revolves around the basis of revenge. Therefor this is not something new.

10. The Malays like amuk.

Reply: Rampage, there is a cause of someone amuk. No one will do that for any reason. It involves uncontrollable emotions as he is insulted and feels too much and can't take it anymore, the solution is to amuk. This also happens in the west.

11. Even though the Malays prefer to be kind, they are actually expecting a reply.

Reply: Sometimes people do something and thought about a reply in return, especially when someone who asks for a help when needed, of course we will do whatever necessary to help especially to a friend. We also hope to get the same reply from him if helping hand is needed someday, is this not normal? In this regard we also want to give assistance to people who have helped us.

12. The Malays are very concerned about their status and class, especially in matters of marriage. If Swettenham remember the story of Romeo and Juliet, I am sure he is aware of the, Westerners are also very concern about their status and class. There are a few more examples, again based on the story of human class differences occur in Europe. During the English invasion of Malaya things are even worse as 
it practiced by the British, namely where there is a certain place reserved only to the white only.

Regarding Swettenham's view towards Malays I find it is typical as a white man view of other groups. They are always superior to others. They can come up with Swettenham's kind of statement, hence peoples believe in this kind of statement. But now, this matter is not to be taken lightly. We should look for the records that the former colonists had written about us and correct the things that are not true about us. The discussion or the answer given to Swettenham attempts to give a balance to his views about the Malays. The affairs about the Malays recorded by him were also happen in Western and English life itself.

The generalizations made about the lives of the Malays were very unfair. This is because the characteristics of the Malays are viewed negatively by Swettenham. It is as if the white men have no such nature. That is the view of the Malay life pattern they believed for hundreds of years. But as humans they are just like the Malays. All the negative statements stated by Swettenham about the Malays can be found in their own culture through their literature and history. This is what happens in the past.

Today, from self-driving cars to drone-delivered online shopping, the Fourth Industrial Revolution is changing how we live, work, and communicate. But with more and more jobs being taken over by artificial intelligence, what do we do? What do literature students today need to do to stay relevant for future job markets? The Fourth Industrial Revolution is expected to change how we live, work, and communicate, it is also likely to change the things we value and the way we value them in the future. Presently, we can already see changing business models and employment trends. This will be a great challenge for us in the field of languages and literature.

According to Utusan Malaysia (2017), The World Economic Forum, an estimated 65\% of kids enrolling in primary education today will end up working in jobs that haven't been created yet. Automation and artificial intelligence are change agents in the fourth Industrial Revolution that will make certain groups of employees redundant, replacing them with new workers with the needed skills or with machines that do the job cheaper. Gone are the days where students go to college or university to study for a degree that will set them up with a job for life. Where is the slot for language and literature studies? The industrial revolution had previously made a change to the methods and processes of production, the fourth revolution would go beyond this and impact each sector from production to management to government governance. In fact, this revolution will challenge ideas about life, reality and the nature of humanity itself. 


\section{Conclusion}

Whether ready or not we have no choice we need to prepare ourselves for the coming Industrial Revolution 4.0 because it will involves all aspects of life not only in terms of material but also in the literature and culture. Malaysia and Indonesia are considered two developing countries due to in many ways we are just the consumers of the product from developed countries. Media and ict role is enough to defeat us in our own home ground. For example the youngsters seems enjoy playing games or get connected with a social media, until they forget the moral values while with parents and friends as they stay attached to the smartphone all the time.

Will this upcoming revolution bring along the mindset of looking down upon us the people from countries that have been colonized such as Malaysia or Indonesia? That will be the point to ponder. What we could do in order to make sure that this will not going happen again we must reinforce the English language skills as well as other foreign languages as well, enhance the work of literature that deals with humanitarian issues. It is certainly without sacrificing the values of religion and tradition that we have been practicing all this while living in peace and harmony. This will be evidence that we are also equivalent to peoples live in the developed country. If others could "sketch" our life as they wish from their point of view, we too could do the same.

\section{References}

[1] Alatas,Syed Hussein. (1977). The Myth of the Lazy Native. London: Frank Cass.

[2] Alexandre Dumas. (2004) The Count of Monte Cristo, Barnes \& Noble Books, New York.

[3] Andaya,L.Y and B.W.(2001). A History of Malaysia. University of Hawaii Press: Hawaii.

[4] Ashcroft,Bill,Gareth Griffits and Helen Tiffin.(1989).The Empire Writes Back.London:Routledge.

[5] Avineri,Shlomo. (Ed.). (1969) Karl Marx on Colonialism and Modernization, New York: Anchor Book.

[6] Badriyah Haji Salleh.(1999). Warkah Al-Ikhlas 1818-1821. Kuala Lumpur:Dewan Bahasa dan Pustaka.

[7] Barry,Peter.(1995). Beginning Theory: An Introduction To LiteraryTheory. United Kingdom: Manchester University.

[8] Press.Boehmer,H.(1995). Colonial and Postcolonial Literature. Oxford: Oxford University Press. 
[9] Bolton, G.C.(1973). Britain's Legacy Overseas.London: Oxford University Press.

[10] Boggs, Carl. (1993). Intellectuals And The Crisis Of Modernity. New York: State Press.

[11] Bottom, J.C. (1960) Abdullah:Ahli Tradisi atau Tokoh Pembaharuan? Dewan Bahasa IV:1h/m.642-647.University Of New York Press.

[12] C. Skinner (1978), Transitional Malay literature: Part 1 Ahmad Rijaluddin and Munshi Abdullah In: Bijdragen tot de Taal-, Land-en Volkenkunde 134 no: 4, 466-487: Leiden.

[13] Swettenham, Frank (1895) Malay Sketches: London: John Lane:New York: Macmillan \& Co

[14] Utusan Malaysia (2017) Berita Luar Negara: Utusan Publication: Kuala Lumpur

[15] Etymology Dictionary, (c) 2010 Douglas Harper 